\title{
Colonic Necrosis Induced by Calcium Polystyrene Sulfonate
}

\author{
Helena Ribeiro Eduardo Pereira António Banhudo \\ Gastroenterology Department, Amato Lusitano Hospital, Castelo Branco, Portugal
}

Keywords

Calcium polystyrene sulfonate $\cdot$ Colon $\cdot$ Necrosis

\section{Necrose do cólon induzida por polistireno sulfonato de cálcio}

\section{Palavras Chave}

Polistireno sulfonato de cálcio · Cólon · Necrose

A 72-year-old male patient presented to the emergency department with a 4-day history of fever and abdominal pain, without altered bowel habits or hematochezia. He had a past medical history of diabetic end-stage renal disease on hemodialysis, ischemic heart disease, and arterial hypertension. The patient was medicated with oral calcium polystyrene sulfonate(CPS), bisacodyl, carvedilol, acetylsalicylic acid, insulin, amlodipine, and ramipril. He was hemodynamically stable and had a painful abdomen with no signs of peritoneal irritation on examination. Laboratory tests showed an increased C-reactive protein level $(183.2 \mathrm{mg} / \mathrm{L})$ with a normal white blood count $(9,850$ leukocytes $/ \mu \mathrm{L})$, hyponatremia $(128 \mathrm{mmol} / \mathrm{L})$, mild decreased serum albumin $(3.3 \mathrm{~g} / \mathrm{dL})$, and normal serum levels of potassium $(4.7 \mathrm{mmol} / \mathrm{L})$ and of lactate dehydrogenase (497 U/L). Abdominal-pelvic computed tomogra-

\section{KARGER}

E-Mail karger@karger.com www.karger.com/pjg
(C) 2017 Sociedade Portuguesa de Gastrenterologia Published by S. Karger AG, Basel

Karger

Open access

This article is licensed under the Creative Commons AttributionNonCommercial-NoDerivatives 4.0 International License (CC BYNC-ND) (http://www.karger.com/Services/OpenAccessLicense) Usage and distribution for commercial purposes as well as any distribution of modified material requires written permission. phy scan revealed thickening of the right colon wall, no free peritoneal fluid or evidence of pneumoperitoneum. The patient was admitted and 1 day later a colonoscopy was performed, showing a congestive and ulcerated mucosa in the right colon and a deep necrotic ulcer in the cecum, with a diameter of $40 \mathrm{~mm}$ (Fig. 1). Taking into account these findings, the main differential diagnosis was either ischemic colitis or infectious colitis. The patient started empiric antibiotic therapy and renal function was stabilized. Pathologic and microbiological examinations excluded infectious colitis, namely tuberculosis, cytomegalovirus or Clostridium difficile colitis. Biopsies from the cecal ulcer revealed necroinflammatory and granulation tissue containing basophilic-stained polystyrene sulfonate crystals (Fig. 2). Thus, the diagnosis of necrosis of the colon induced by CPS was considered. Six days after the admission, the patient experienced worsening of the abdominal pain. An abdominal ultrasound was performed the following day and revealed an abscess adjacent to the ulcer of the cecum (Fig. 3). The abscess may reflect a microperforation of the cecum that could be an iatrogenic event related to the colonoscopy or, less probably, a spontaneous event facilitated by the presence of the large ulcer and transmural necrosis. The microperforation was successfully managed with a single ultrasoundguided needle aspiration of the abscess and with conservative medical treatment. CPS was suspended, the patient started a more restrictive potassium diet, and the hemo- 


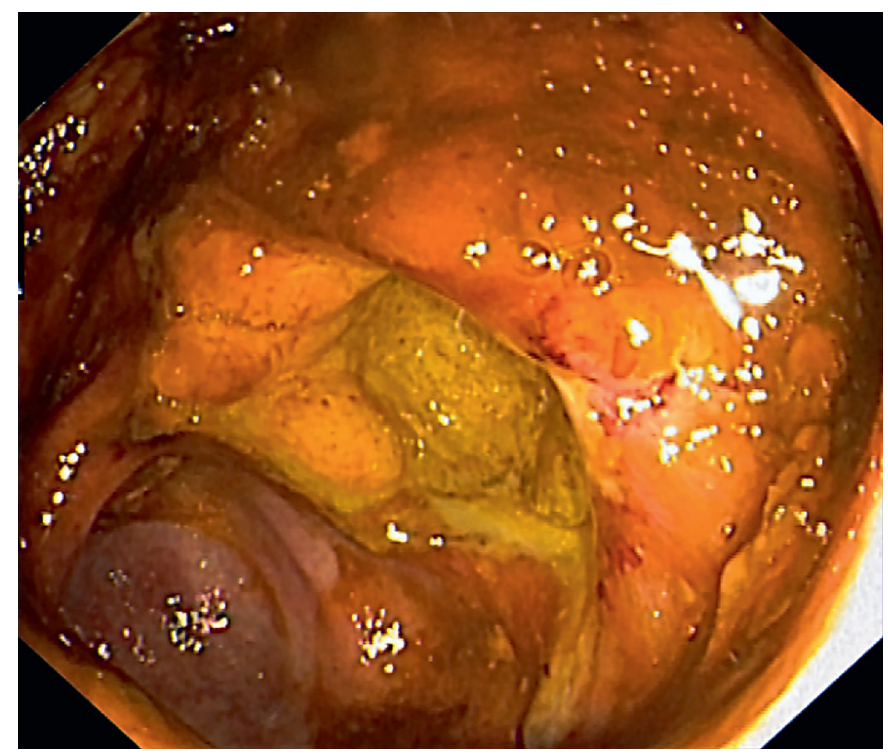

Fig. 1. Endoscopic view of the deep necrotic ulcer in the cecum with a diameter of $40 \mathrm{~mm}$.

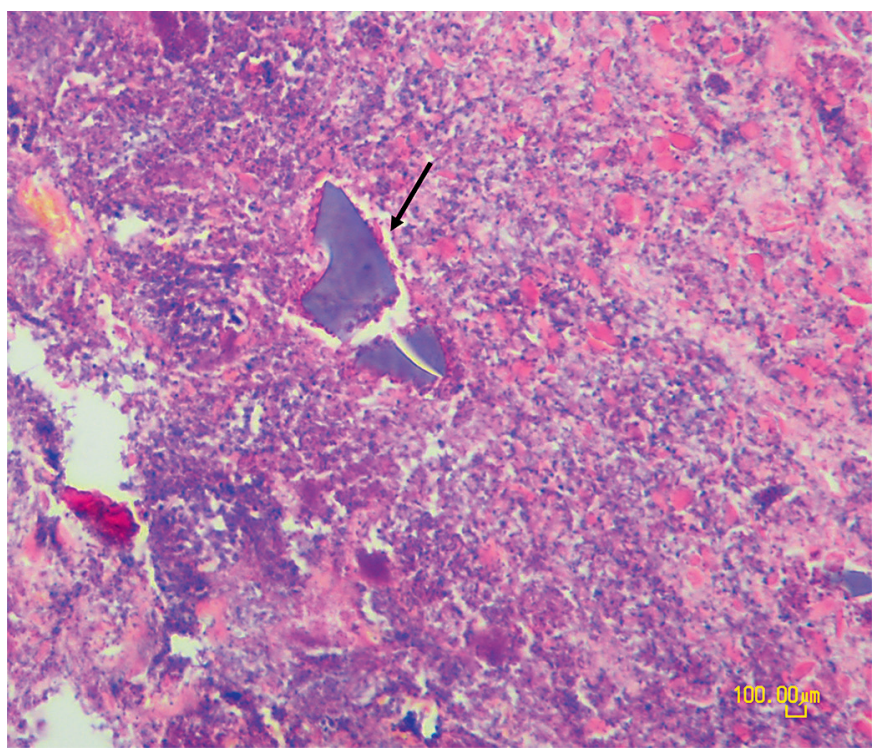

Fig. 2. Histological image of the necroinflammatory and granulation tissue containing basophilic-stained polystyrene sulfonate crystals, with a mosaic pattern (arrow).

dialysis was optimized in order to control hyperkalemia. He presented a favorable clinical evolution. Ten weeks later, colonoscopy was normal (Fig. 4).

CPS is a cation exchange resin used in hyperkalemia treatment. Colonic lesions have been described as adverse events of CPS; however, they are more often reported fol-

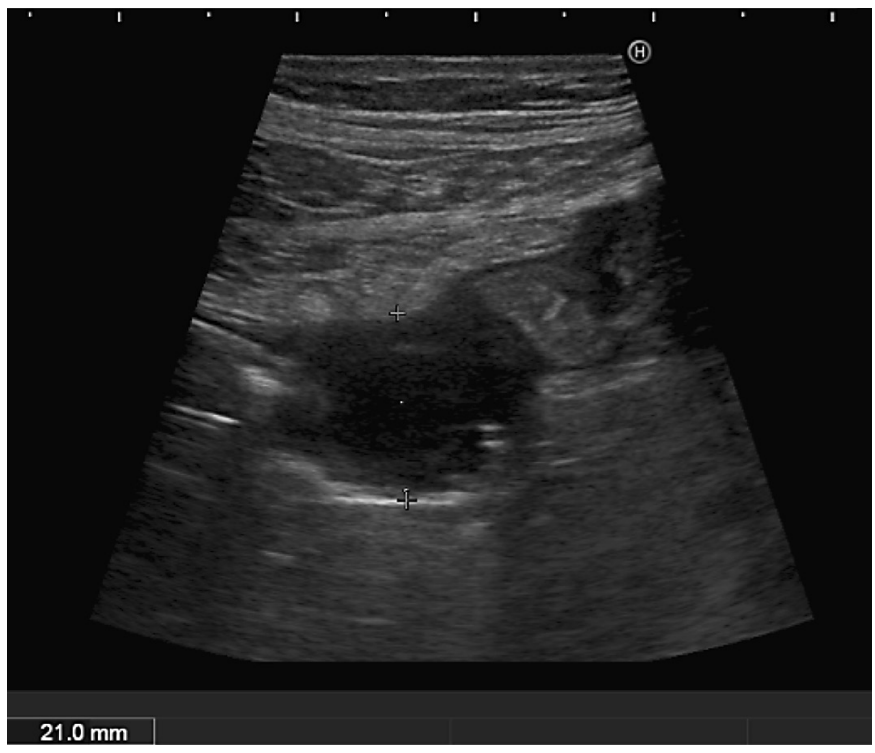

Fig. 3. Ultrasound image of the abscess adjacent to the ulcer in the cecum, with a diameter of $21 \mathrm{~mm}$.

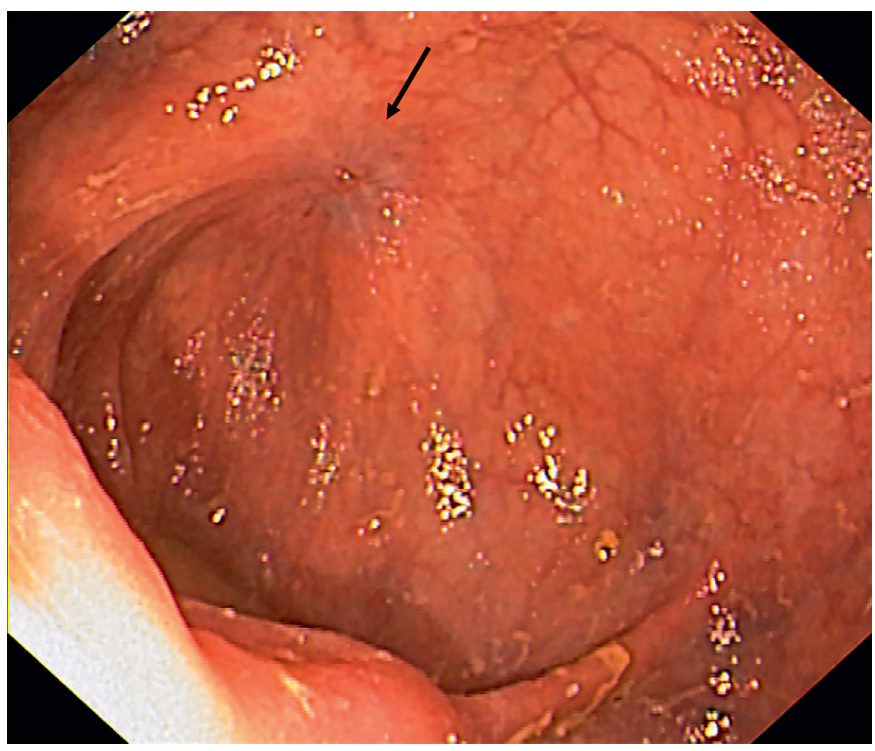

Fig. 4. Endoscopic view of the cecum with complete healing of the ulcer and evidence of a small scarred area (arrow).

lowing treatments with a similar resin, sodium polystyrene sulfonate, usually mixed with sorbitol [1-3]. Although the mechanism of mucosal injury is unclear, crystal deposit within the intestinal wall may directly damage the mucosa along with vascular risk factors contributing to intestinal ischemia $[1,2]$. We report a case of colonic 
necrosis induced by CPS, complicated by a contained microperfuration of the cecum, a rare but serious adverse event of this drug, with only a few similar cases reported in the literature.

\section{Acknowledgements}

All authors participated in the drafting and critical revision of the article and Dr. António Banhudo was responsible for the final approval of the manuscript.

\section{Statement of Ethics}

This study did not require informed consent nor review/approval by the appropriate ethics committee.

\section{Disclosure Statement}

The authors have no conflicts of interest to declare.

References

1 Castillo-Cejas MD, de-Torres-Ramírez I, Alonso-Cotoner C: Colonic necrosis due to calcium polystyrene sulfonate (Kalimate) not suspended in sorbitol. Rev Esp Enferm Dig 2013 Apr;105:232-234.

2 Harel Z, Harel S, Shah PS, Wald R, Perl J, Bell CM: Gastrointestinal adverse events with sodium polystyrene sulfonate (Kayexalate) use: a systematic review. Am J Med 2013;126:264. e9-24.

3 Akagun T, Yazici H, Gulluoglu MG, Yegen G, Turkmen A: Colonic necrosis and perforation due to calcium polystyrene sulfonate in a uraemic patient: a case report. NDT Plus 2011;4:402-403. 